\title{
Music therapy - an alternative form supporting the quality of mother and baby care
}

\author{
Agnieszka Dombrowska-Pali, Grażyna Gebuza, Marzena Kaźmierczak, Małgorzata Gierszewska, \\ Estera Mieczkowska
}

Department of Obstetric Care Basics, Faculty of Health Sciences, Collegium Medicum in Bydgoszcz, Nicolaus Copernicus University in Toruń, Poland

\section{ABSTRACT}

Based on numerous pieces of clinical evidence, music has been used more and more frequently in obstetrics. During the prenatal development it is received both by the mother and by the developing foetus. The baby reacts to the voice of its parents, responding by intensified activity, which corresponds to the increase in the number of its movements. It reacts similarly to everyday sounds and music. Listening to music improves the health of women, who are exposed to stress during pregnancy. Therefore, implementing minor changes in those units may significantly change the lives of babies and women. Music therapy is also recommended to women during and after giving birth. Music significantly affects the natural feeding, ensuring the health of mother and baby. It influences the baby's intelligence, developing its mathematical, analytical, and linguistic capacities. Stimulation by music may significantly enhance the quality of care of newborns and pregnant women.

\section{KEY WORDS:}

music therapy, pregnancy, labour pain, stress during pregnancy.

\section{INTRODUCTION}

The therapeutic influence of music on the human body has been in the centre of attention of physicians, who initially observed, and later conducted research, using music as a therapeutic tool in healing processes $[1,2]$. Music is currently applied as a form of therapy complementing and supporting traditional treatment methods. Music alleviates physical and mental ailments $[2,3]$. Applying various types of music in order to improve the patient's mood and support the treatment may result in improved health, increased quality of life, and longer lifespan [4]. Listening to music evokes numerous emotional states that are reflected in the functioning of internal organs and manifest themselves in changes re- garding arterial blood pressure, heart rate, metabolism, and inhaled minute volume [5]. Music therapy has a substantial influence on one's mental sphere. Its main task is to relieve the emotional tension, lower the stress level, and help in achieving a relaxed state of mind, as well as in establishing interpersonal relationships [6]. Music results in a decreased cortisol level (the stress hormone) as well as in improved quality of sleep [7]. An appropriately selected and prepared music material lowers the intensity of anxiety and depression symptoms [8]. As a therapeutic tool, music was initially used in the treatment of psychiatric disorders [1]. Nowadays, it is widely applied in reablement, palliative care, and relaxation, as well as in ophthalmology, orthopaedics, and cardiology [7], but also in the case of neoplastic diseases [9]. Music sessions are

\section{ADDRESS FOR CORRESPONDENCE:}

Agnieszka Dombrowska-Pali, Department of Obstetric Care Basics, Faculty of Health Sciences, Collegium Medicum in Bydgoszcz, Nicolaus Copernicus University in Toruń, 1 Łukasiewicza St., 85-821 Bydgoszcz, Poland, e-mail: agnieszka.pali@cm.umk.pl 
also used in obstetrics. During the prenatal period music is experienced as a natural stimulus from the external environment, it positively stimulates and affects both the organism of a woman as well as a developing foetus [7].

\section{AN OVERVIEW OF STUDIES}

The prenatal period is within the scope of interest of various sciences, including prenatal psychology, which is strictly connected to perinatal, reproductive, and family psychology [10]. Literature on the subject analyses the therapeutic application of music in the prenatal period in relation to women as well as in the context of a developing foetus [11]. Due to the research the conviction regarding prenatal period that treated "a foetus as a conglomerate of specialised cells and organs that is only physiologically active, does not feel and, apart from that, is passive as well as dependant" $[12,13]$. An infant feels and reacts before being born, and its physical activity depends on the stimuli that it is exposed to. The findings of scientists enabled us to determine how essential sound and the mother's voice are in the foetal life as well as how the organ of hearing and the auditory centre are shaped in the prenatal period [10]. During foetal life, hearing is the sense that develops first $[14,15]$.

At the beginning, an infant is most sensitive to vibrations, later to strong individual sounds, and then it becomes much more sensitive to more gentle sounds. Mothers report that their babies start to move within a few seconds after they hear a loud sound. They observe increased mobility of the foetus while listening to loud music [10]. The studies by Deliege and Sloboda showed that an infant can hear its mother's heartbeat, blood circulation, its own movements in the amniotic fluid, as well as the sound of its own heart. Other findings indicate that a foetus hears the voice of its mother and is able to experience the vibrations of her auditory cortex [16] and the functioning of the intestines. It reacts to sounds of various intensity, recognising them as stimuli, but does not have the awareness to differentiate between them [17].

In a study conducted by Doheny et al. the therapeutic influence of music on the health of infants that were prematurely born was observed. Scientists using the tones of heartbeats and the voice of the mother found that the frequency of apnoea was lower than in premature babies exposed to the sound of medical equipment [18]. It was also shown that stimulation with the mother's voice and her heartbeat influences the proper development of the cerebral cortex in prematurely born infants [19]. The studies conducted by Spelt and Sontage as well as by Newbery proved that a multiple repetition of loud sounds near the mother's abdomen results in faster heartbeats as a response to the sound [17]. Poręba et al., when conducting a study on a group of pregnant women, used relaxing, activating, and stimulating music. An analysis of cardiographic parameters (CTG) proved that foetuses displayed various reactions to different types of music. It was observed that the frequency of the movements of foetus and uterine contractions increased [20]. Thanks to the application of music, foetuses scored higher results in a cardiotocographic examination, which speaks of their well-being. It was shown that the number of movements of the foetus increased in pregnant women who were exposed to classical music compilations by M. Ravel [14]. At the same time, music compilations by J. Strauss and W.A. Mozart caused an increase in the number of foetus movements. They were of short term and high volatility. The researchers concluded that usage of music may shorten the time necessary for an NST (non-stress test) [21].

Listening to music also influences vital parameters of pregnant women; it lowers arterial blood pressure [22]. Therefore, the use of music in the care of pregnant women with pre-eclampsia is justified [23].

Scientists made interesting observations while conducting an ultrasound examination. It turned out that stimulating a foetus with music results in an increased number of movements of its mimic muscles. It was only in foetuses exposed to sound stimuli that characteristic movements of lips - the movements of oral cavity - were observed. Scientists believe that in the future, stimulating a foetus with music while at the same time observing its behaviour in an ultrasound image may become an introductory diagnostic examination of hearing [24]. An appropriate usage of music gives the expected results $[11,14]$. Music compilations that pregnant women listen to are memorised by the foetus creating so-called prenatal memory [25]. During the prenatal period one can observe a learned reaction of a foetus, which is based on classical conditioning. Even though a foetus has a limited ability to learn, it recognises, memorises, and reacts to a given music material. This makes it possible to predict the reaction of a foetus to a music material that was memorised before [16].

An infant's auditory memories last for at least six weeks [25]. It is possible to communicate with an infant after its birth via the means of auditory stimuli that date back to its prenatal period. This is why it is possible to make an infant feel calm with the usage of music that it knows from its prenatal period. Other studies show that the sound of heartbeats gives babies a sense of security. Babies cried less, developed better, their breath was calmer, and it was possible to observe a faster increase in their body mass after they listened to their mothers' heartbeat sounds [11]. Memories related to music decrease the heart rate in newborns, and they influence an infant's general development after its birth [25]. Babies that were stimulated with music during their prenatal period are calmer and more concentrated on objects after their birth. A more intensive development of speech can also be observed. Babies display a greater ability to walk, stand up, and sit. Intellectual functions, aesthetic sensitivity, and creative skills are also reported to be higher. Music therapy helps in expressing emotions and results in easier es- 
tablishment of contacts, activates cognitive processes, and increases self-esteem [11].

Music has a positive influence on the psychophysical condition of women [26] and foetuses. Having listened to music, women feel an influx of energy and have a sense of security. Music lowers psychological and muscle tension, improving the general mood of women [11]. It affects the quality of sleep [27]. The emotions experienced by women have an influence on foetuses [28]. Based on their research, Sarkar and others claim that the anxiety experienced by a mother during the prenatal period may have an impact on the functioning of the placenta, which stimulates the exposure of the foetus to the high level of cortisol in its mother, and as a result it affects the foetus by disturbing its developmental processes [29]. The shrinking of blood vessels under the influence of cortisol as well as shallow and short breathing of the mother may cause hypoxia in the foetus. Stress is also to blame for the weakening of the female immune system, which causes frequent infections [30].

Negative emotions experienced by pregnant women have a considerable influence on the development of an infant's brain. In the case of older babies, one can observe problems with focusing and concentration. In adolescence those babies display antisocial behaviours [31]. Other findings show that the stress experienced by pregnant women makes them more likely to give birth to an infant with schizophrenia, autism, and ADHD (attention deficit hyperactivity disorder). The mechanism of the hypothalamic-pituitary-adrenal axis is responsible for the occurrence of those diseases [32]. Using magnetic resonance, it was found that women who experienced negative emotions including depression gave birth to babies with an increased amygdala. Those structures regulate emotions and are responsible for the feeling of anxiety, aggression, and panic [33]. Therefore, mental hygiene in the prenatal period is crucial - it gives a mother and her infant a chance for optimal development and health. It is vital to experience positive emotions. This can be fostered by relaxing and listening to music. A music compilation that evokes a positive response lowers the secretion of corticotropin and cortisol - the hormones that are responsible for stress reactions [34]. It turned out that music protects from the detrimental, long-term effects of cortisol [2], which has a negative influence on the nervous and immune systems [35].

Maternal-foetal medicine attributes great meaning to lullabies, which make babies feel calm by giving them a sense of security. The voice of its mother gives the foetus and the newborn a sense of peace and stability [36]. The positive effect of stimulation with a mother's voice can be observed in prematurely born infants. They display lower heart rate [37], higher stability of skin colour, and better quality of movements [38]. Therefore, mothers should be encouraged to sing or listen to lullabies.

The positive influence of music was also observed in neonatal units. Music therapy makes it possible to achieve the optimal level of carbonation both in babies born in due time [36] and in prematurely-born ones [39]. Music has an influence on the pace of the development of the infant's head and its sucking reflex [36]. It normalises pulse, body temperature, and breathing [40], lowers the heart rate, and calms prematurely born infants [39]. A higher daily body mass rate [11], fewer cases related to non-tolerance of breastfeeding [41], and shorter hospitalisation time [42] can be observed in newborns stimulated by music. It was proven that music performed live has an influence on newborns' deeper and calmer sleep as well as on a lower pulse rate [36]. Much better results can be observed when music therapy is connected with the direct contact of an infant's body with the body of its parent - kangaroo care [43].

Music is applied during childbirth to reduce the pain and ensure relaxation [11]. It has been proven that listening to music increases the secretion of peptide hormones - endorphins, which relieve pain, making women achieve a state of euphoria and bliss [44]. In obstetrics, the cause and effect sequence of anxiety - tension - pain is well known. This phenomenon explains that anxiety and tension are factors influencing the experience of pain during childbirth. The use of relaxation music in a delivery room reduces the level of tension and anxiety, and thus increases the pain threshold [45-47]. This results in a reduced amount of pharmacological medicaments taken by the mother, which lowers the risk of side effects in the mother and in the foetus [11]. A reduced level of anxiety, stress, and pain that follows listening to music is also observed in pregnant women waiting for a Caesarean section [46]. It can be seen that music helps women who are giving birth to concentrate, it normalises blood pressure, and lowers psychophysical tension [48]. It improves ventilation and makes it easier for women to adopt vertical positions, as well as to perform relaxation and breathing exercises $[11,48]$. Other observations indicate that music therapy shortens the time of the first stage of childbirth to two hours [49]. The childbirth is faster, less stressful and more conscious [50]. It is crucial that a woman chooses music because it influences her behaviour, mood, and the manner in which she experiences the childbirth. Therefore, it should be chosen according to her preferences, but its pace should be similar to her heart rate. Calm music is recommended at the first stage of childbirth, while during the second stage, sounds mobilising effort can be applied [51]. The studies by Poręba et al. confirm the influence of music on the course of childbirth. The results indicate that the frequency of uterine contractions during childbirth increased together with the increasing tempo of the music. This method can become an alternative to strengthening contractions during childbirth when they are ineffective [20]. It transpired that the singing of a woman giving birth proved to be an important element increasing the completion of childbirth. It caused a state of relaxation, improvement of well-being, and lower level of mental tension. It was observed that singing relaxes the muscles of the lips, 
larynx, face, lower parts of the abdomen, and pelvis, which leads to the smooth course of childbirth. Frequent singing activates the respiratory muscle - the diaphragm. It also increases the inhaled minute volume, the amplitude of the diaphragm's mobility, which results in better oxygenation both of a woman and her infant.

According to Stodolak and Pietras, singing while giving birth shortens the time needed for childbirth [52]. Listening to music during childbirth increases the satisfaction with it, reduces anxiety and pain in the post-partum period, and reduces the intensity of the early stage of postpartum depression [47]. Women giving birth required fewer pharmacological medicaments [53].

It their study, Gebuza et al. showed that listening to classical music reduces the number of uterine contractions. This, in turn, can be applied as a form of prevention in cases where there is a risk of premature delivery. Moreover, listening to classical music results in an increased number of the foetus' movements in the case of non-reactive non-stress test (NST) [54]. Music is also applied as a form of psychotherapy in women whose pregnancies are at risk of a miscarriage. The main aim was to reduce anxiety and tension caused by the fear of losing an infant [11]. In the first weeks of pregnancy, stress increases the risk of miscarriage. In the following weeks, however, adrenaline released during stress can cause uterine contractions and cervical dilation. This, in turn, causes a threat of premature childbirth and, consequently, low birth weight of a new born who is not fully prepared to live outside its mother's body. Newborns who have experienced prolonged stress during their prenatal period have problems with breathing, they are irritable, more tearful, and have a disturbed rhythm of sleep and wakefulness [30]. It is important that pregnant women can take care of their own mental health. Observations show that music therapy is a cheap, simple, and non-invasive method that effectively reduces stress and lowers the level of depression [55]. It turns out that music also supports the lactation process. The studies carried out amongst mothers of premature babies at the Neonatal Intensive Care Unit indicate that music evoked an increase in the amount of expressed breast milk. Having listened to musical compilations from Hindu culture, women scored a lower level of the stress hormone, cortisol, in their saliva. Decreased anxiety also contributed to better coping with the sense of uncertainty and anxiety connected with the stay of babies in the hospital [34]. It was observed that the breast milk of mothers who listened to music contained more and more fat with every day [56].

\section{CONCLUSIONS}

Pregnant women who listen to music provide their babies with optimal conditions for development. Music influences the development of human experience and sensitivity, and it shapes the personality of both adults and babies. Pregnant women should be encouraged to listen to music in their daily lives because it is a cheap and non-invasive method that helps the mother and her infant to achieve a state of relaxation. Stimulation with music relieves emotional tension, and reduces stress, anxiety, and depression. It results in better sleep and a higher pain threshold of future mothers. It affects both physical and mental spheres. Positive effects of music are also observed in risk-pregnancy women. Calm music relaxes the muscle of the uterus, and reduces its tension and frequency of contractions, lowering the risk of pre-term childbirth. The benefits of listening to music throughout the prenatal period are confirmed. Music activates various brain structures in women and in babies. Bearing in mind the well-being of an infant, parents should allow for stimulation with appropriate music in the period when their infant receives sounds spontaneously, when there are no habits or associations. Moreover, music enriches an infant's inner world. It should be stressed that music supports breastfeeding as well as the development of bonds ensuring the optimal development and health of an infant. It is a challenge for the medical personnel to make it possible that music becomes one of the elements of therapy in maternity and neonatal units.

\section{DISCLOSURE}

The authors declare no conflict of interest.

\section{REFERENCES}

1. Kronenberger M. Muzykoterapia: podstawy teoretyczne do zastosowania muzykoterapii w profilaktyce. Mediatour, Szczecin 2003.

2. Paszkiewicz-Mes E. Muzykoterapia jako metoda wspomagająca leczenie. Hygeia Public Health 2013; 48: 168-176.

3. Mahon EM, Mahon SM. Music therapy: a valuable adjunct in the oncology setting. Clin J Nurs Oncol 2011; 15: 353-356.

4. Nowak M. Muzykoterapia źródłem stymulacji dla wcześniaków. In: Stachyra K, Handford O (Eds.). Terapia przez Sztukę. PSTS, Lublin 2011: 26-29.

5. Metera A. Muzykoterapia: muzyka w medycynie i edukacji. Wydawnictwo Centrum Technik Nauki Metronom, Leszno 2006.

6. Żychlińska M, Florkowski A, Furmańska A, et al. Wpływ efektów terapii zaburzeń nerwicowych i związanych ze stresem na wybrane aspekty funkcjonowania psychologicznego. Pol Merkur Lek 2008; 25: 20-22.

7. Gąsienica-Szostak A. Muzykoterapia w rehabilitacji i profilaktyce. PZWL, Warszawa 2003.

8. Maratos A, Crawford MJ, Procter S. Music therapy for depression: it seems to work, but how? Br J Psychiatry 2011; 199: 92-93.

9. Bradt J, Dileo C, Grocke D, Magill L. Music interventions for improving psychological outcomes in cancer patients. Cochrane Database Syst Rev 2011; 8 :CD006911.

10. Harwas-Napierała B, Trempała J. Psychologia rozwoju człowieka. Charakterystyka okresów życia człowieka. Wydawnictwo Naukowe PWN, Warszawa 2007.

11. Kędziora S. Znaczenie muzyki w okresie prenatalnym. In: UchyłaZroski J. (Ed.) Wartości w muzyce. Muzyka w środowisku społecznym. Wydawnictwo Uniwersytetu Śląskiego, Katowice 2012: 288-299. 
12. Chamberlain DB. Psychika noworodka: wzrastające dowody kompetencji. Nowiny Psychol 1986; 8: 44-52.

13. Chamberlain DB. Babies are not What We Thought: Cali for a New Paradigm. Int J Prenatal Perinatal Studies 1992; 4: 1-17.

14. Gebuza G, Szewczyk M, Kaźmierczak M, et al. Ocena czynności serca płodu w III trymestrze ciąży podczas słuchania utworów Maurice’a Ravela i Johanna Straussa. Nowa Pediatr 2015; 19: 144-149.

15. Cheour-Luhtanen M, Alho K, Sainino K, et al. The ontogenetically earliest discriminative response of the human brain. Psychophysiology 1996; 33: 478-481.

16. Kornas-Biela D. Wokół początku życia ludzkiego. PAX Instytut Wydawniczy, Warszawa 2004.

17. Kornas-Biela D. Pedagogika prenatalna. Nowy obszar nauk o wychowaniu. Wydawnictwo KUL, Lublin: 2009.

18. Doheny L, Hurwitz S, Insoft R, et al. Exposure to biological maternal sounds improves cardiorespiratory regulation in extremely preterm infants. J Matern Fetal Neonatal Med 2012; 25: 1591-1594.

19. Królak-Olejnik B. Znaczenie dźwięku dla noworodka przebywającego w inkubatorze w oddziale intensywnej terapii. In: Muzyka w życiu człowieka. Hirnle L (Ed.). Wrocławskie Wydawnictwo Naukowe Atla 2, Wrocław 2016: 35-48.

20. Poręba A, Dutkiewicz D, Drygalski M. Wpływ dźwięków muzycznych na zachowanie się wybranych parametrów kardiotokograficznych u kobiet w ciąży donoszonej. Ginekol Pol 2000; 71: 915-920.

21. Gebuza G, Dombrowska A, Kaźmierczak M, et al. The effect of music therapy on the cardiac activity parameters of a fetus in a cardiotocographic examination. J Matern Fetal Neonatal Med 2017; 30: 2440-2445.

22. García González J, Ventura Miranda MI, Manchon García F, et al. Effects of prenatal music stimulation on fetal cardiac state, newborn anthropometric measurements and vital signs of pregnant women: A randomized controlled trial. Complement Ther Clin Pract 2017; 27: 61-67.

23. Toker E, Kömürcü N. Effect of Turkish classical music on prenatal anxiety and satisfaction: A randomized controlled trial in pregnant women with pre-eclampsia. Complement Ther Med 2017; 30: 1-9.

24. Reissland N, Francis B, Buttanshaw L, et al. Do fetuses move their lips to the sound that they hear? An observational feasibility study on auditory stimulation in the womb. Pilot Feasibility Stud 2016; 2: 14.

25. Granier-Deferre C, Bassereau S, Ribeiro A, et al. A Melodic Contour Repeatedly Experienced by Human Near-Term Fetuses Elicits a Profound Cardiac Reaction One Month after Birth. PLoS ONE 2011; 6: e17304.

26. Chang MY, Chen $\mathrm{CH}$, Huang KF. Effects of music therapy on psychological health of women during pregnancy. J Clin Nurs 2008; 17: 2580-2587.

27. Liu YH, Lee CS, Yu CH, et al. Effects of music listening on stress, anxiety, and sleep quality for sleep-disturbed pregnant women. Women Health 2016; 56: 296-311.

28. DiPietro JA, Costigan KA, Gurewitsch E. Fetal response to induced maternal stress. Early Hum Dev 2003; 74: 125-138.

29. Sarkar P, Bergman K, O'Connor T, et al. Maternal antenatal anxiety and amniotic fluid cortisol and testosterone: possible implications for foetal programming. J Neuroendocrinol 2008; 20: 489-496.

30. Szydełko J, Szydełko M, Piątek D, et al. Wpływ chronicznego stresu u kobiet w ciąży na kształtowanie się zachowań żywieniowych u ich potomstwa w życiu postnatalnym. Medical Review 2016; 14: 83-92.

31. DiPietro JA. The Role of Prenatal Maternal Stress in Child Development. Am Psychol Soc 2004; 13: 71-73.

32. Jośko-Ochojska J, Kasperczyk J, Marcinkowska U, et al. Negatywne emocje w świecie dziecka. Przegl Pediatr 2012; 42: 208-212.

33. Lupien SJ, Parent S, Evans AC, et al. Larger amygdala but no change in hippocampal volume in 10 -year-old children exposed to maternal depressive symptomatology since birth. Proc Natl Acad Sci USA 2011; 108: 14324-14329.
34. Ak J, Lakshmanagowda PB, G C M P, et al. Impact of music therapy on breast milk secretion in mothers of premature newborns. J Clin Diagn Res 2015; 9: CC04-6.

35. Zimecki M, Artym J. Wpływ stresu psychicznego na odpowiedź immunologiczną The effect of psychic stress on the immune response. Postepy Hig Med Dosw 2004; 58: 166-175.

36. Nowak M. Muzykoterapia źródłem stymulacji dla wcześniaków. Terapia przez Sztukę 2011; 1: 26-29.

37. Rand K, Lahav A. Maternal sounds elicit lower heart rate in preterm newborns in the first month of life. Early Hum Dev 2014; 90: 679-683.

38. Picciolini O, Porro M, Meazza A, et al. Early exposure to maternal voice: effects on preterm infants development. Early Hum Dev 2014; 90: 287-292.

39. Desquitos-Sunnen N. Singing for preterm born infants music therapy in neonatology. Bull Soc Sci Med Grand Duche Luxemb 2008; 1: 131-143.

40. Ludington-Hoe S, Lewis T, Morgan K, et al. Breast and infant temperatures with twins during shared kangaroo care. J Ostet Gynecol Neonatal Nurs 2006; 35: 223-231.

41. Krueger C, Parker L, Chiu SH, et al. Maternal voice and short-term outcomes in preterm infants. Dev Psychobiol 2010; 52: 205-212.

42. Cevasco AM. The effects of mothers' singing on full-term and preterm infants and maternal emotional responses. J Music Ther 2008; 45: 273-306.

43. Schlez, Litmanovitz I, Bauer S, et al. Combining Kangaroo care and live harp therapy in The neonatal intensive care unit setting. Isr Med Assoc J 2011; 13: 354-358.

44. Pospiech W. Muzykoterapia służbą człowieka. UMK, Toruń 2009.

45. Liu YH, Chang MY, Chen CH. Effects of music therapy on labour pain and anxiety in Taiwanese first-time mothers. J Clin Nurs 2010; 19: 1065-1072.

46. Wulff V, Hepp P, Fehm T, et al. Music in Obstetrics: An Intervention Option to Reduce Tension, Pain and Stress. Geburtsh Frauenheilk 2017; 77: 967-975.

47. Simavli S, Kaygusuz I, Gumus I, et al. Effect of music therapy during vaginal delivery on postpartum pain relief and mental health. J Affect Disord 2014; 156: 194-199.

48. Smolarek N, Pięt M, Żurawska J, et al. Alternatywne sposoby łagodzenia bólu porodowego. Pol Prz Nauk Zdr 2016; 1: 74-80.

49. Wac K, Krzemień G, Naworska B, et al. Wykorzystanie alternatywnych technik w terapii bólu porodowego. In: Niebrój L, Kosińska M (Eds.). Położnictwo: profesja o wielu aspektach. Wydawnictwo Eukarsia, Katowice 2005: 43-47.

50. Chang SC, Chen $\mathrm{CH}$. The application of music therapy in maternity nursing. Hu Li Za Zhi 2004; 51: 61-66.

51. Sulima M, Golnik E. Alternatywne metody łagodzenia bólu porodowego. Technologie w optymalizacji opieki medycznej. EJMT 2013; 1: 41-47.

52. Stodolak A, Pietras J. Niefarmakologiczne metody analgezji okołoporodowej. Pol Med Rodz 2004; 1: 390-393.

53. Simavli S, Gumus I, Kaygusuz I, et al. Effect of music on labor pain relief, anxiety level and postpartum analgesic requirement: a randomized controlled clinical trial. Gynecol Obstet Invest 2014; 78 : 244-250.

54. Gebuza G, Zaleska M, Kaźmierczak M, et al. The effect of music on the cardiac activity of a fetus in a cardiotocographic examination. Adv Clin Exp Med 2018; 27: 615-621.

55. Nwebube Ch, Glover V, Stewart L. Prenatal listening to songs composed for pregnancy and symptoms of anxiety and depression: a pilot study. BMC Complement Altern Med 2017; 17: 256.

56. Keith DR, Weaver BS, Vogel RL. The effect of music-based listening interventions on the volume, fat content, and caloric content of breast milk-produced by mothers of premature and critically ill infants. Adv Neonatal Care 2012; 12: 112-119. 